\title{
Management of Acute Stroke Patients Amid the Coronavirus Disease 2019 Pandemic: Scientific Statement of the Korean Stroke Society
}

\author{
Beom Joon Kim, ${ }^{\mathrm{a}}$ Eu Suk Kim, ${ }^{\mathrm{b}}$ Myoung Jin Shin, ${ }^{\mathrm{c}}$ Hong Bin Kim, ${ }^{\mathrm{b}}$ Hee Young Lee, ${ }^{\mathrm{d}}$ Keun-Sik Hong, ${ }^{\mathrm{e}}$ \\ Hong-Kyun Park, Jun Lee, ${ }^{\mathrm{f}}$ Sung-Il Sohn, ${ }^{\mathrm{g}}$ Yang-Ha Hwang, ${ }^{\mathrm{h}}$ Sang-Bae Ko, ${ }^{\mathrm{i}}$ Jong-Moo Park, Joung-Ho Rha, ${ }^{\mathrm{k}}$ \\ Sun U. Kwon, ${ }^{1}$ Jong S. Kim, ${ }^{1}$ Ji Hoe Heo, ${ }^{\mathrm{m}}$ Byung Chul Lee, ${ }^{\mathrm{n}}$ Byung-Woo Yoon, ${ }^{\mathrm{i}}$ Hee-Joon Bae ${ }^{\mathrm{a}}$ \\ aDepartment of Neurology and Gyunggi Regional Cardiocerebrovascular Center, Seoul National University Bundang Hospital, Seoul National \\ University College of Medicine, Seongnam, Korea \\ bepartment of Internal Medicine and Infection Control Office, Seoul National University Bundang Hospital, Seongnam, Korea \\ Infection Control Office, Seoul National University Bundang Hospital, Seongnam, Korea \\ ${ }^{d}$ Center for Public Health, Seoul National University Bundang Hospital and Gyeonggi Infectious Disease Control Center, Seongnam, Korea \\ 'Department of Neurology, Inje University Ilsan Paik Hospital, Inje University College of Medicine, Goyang, Korea \\ fDepartment of Neurology, Yeungnam University Hospital, Daegu, Korea \\ ${ }^{9}$ Department of Neurology, Keimyung University Dongsan Medical Center, Daegu, Korea \\ hDepartment of Neurology, Kyungpook National University Hospital, School of Medicine, Kyungpook National University, Daegu, Korea \\ 'Department of Neurology, Seoul National University Hospital, Seoul, Korea \\ 'Department of Neurology, Eulji General Hospital, Eulji University School of Medicine, Seoul, Korea \\ kDepartment of Neurology, Inha University Hospital, Incheon, Korea \\ 'Department of Neurology, Asan Medical Center, University of Ulsan College of Medicine, Seoul, Korea \\ mDepartment of Neurology, Severance Hospital, Yonsei University College of Medicine, Seoul, Korea \\ nDepartment of Neurology, Hallym Neurological Institute, Hallym University Sacred Heart Hospital, Anyang, Korea
}

Timely diagnosis, transportation, and emergent in-hospital care, including recanalization treatment and admission to a dedicated stroke unit, are essential components of acute stroke care. Amid the coronavirus disease 2019 (COVID-19) pandemic, because of the shortage of medical resources and staff, suboptimal stroke care may occur resulting in worse clinical outcomes. ${ }^{1} \mathrm{Ad}-$ ditionally, hospital personnel, including doctors, nurses, and technicians, are at higher risk for exposure to severe acute respiratory syndrome coronavirus 2 (SARS-CoV-2), the virus that causes COVID-19, during emergent stroke care. Therefore, there is an urgent need to provide stroke centers with a tentative guidance to ensure the quality of acute stroke care and the safety of hospital personnel involved in stroke care.

The transmission of SARS-CoV-2 is known to occur through droplets emitted during sneezing, coughing, or a casual conversation. ${ }^{2}$ Patients with COVID-19 usually present with fever, sore throat, cough, chest pain, dyspnea, headache, generalized body aches, vomiting, and diarrhea. Olfactory and gustatory dysfunctions may occur. ${ }^{3}$ The clinical course is mild in most cases, but lower respiratory infections including pneumonia can develop from the early days of illness. ${ }^{2,4}$ Viral shedding may be high during the prodromal phase.

Dizziness and headache may occur in 36\% of COVID-19 cases. Stroke has been reported to occur in 6\% of confirmed COVID-19 patients at a median of 10 days after the initial symptoms. ${ }^{5,6}$ Presumed stroke mechanisms include hypercoagulability because of critical illness and
Correspondence: Hee-Joon Bae Department of Neurology and Cerebrovascular Center, Seoul National University Bundang Hospital, Seoul National University College of Medicine, 82 Gumi-ro 173beon-gil, Bundang-gu, Seongnam 13620, Korea

Tel: +82-31-787-7467

Fax: +82-31-787-4059

E-mail: braindoc@snu.ac.kr

Received: April 16, 2020 Revised: April 20, 2020 Accepted: April 20, 2020 
cardioembolism due to viral myocarditis or cardiac failure.

International stroke societies and organizations are currently working to devise an action plan to provide optimal stroke care amid the COVID-19 pandemic. Their plans can be summarized as follows: (1) centralization of regional stroke systems of care and (2) development and implementation of protected intramural code stroke protocols to ensure the quality of stroke care and protect hospital personnel from the SARS-CoV-2 infection. ${ }^{1,78}$ A recent Chinese guideline for neurologists recommended performing brain and chest computed tomography simultaneously in cases of neurological symptoms or stroke with a high suspicion of COVID-19. ${ }^{9}$

As of mid-April 2020, the COVID-19 epidemic in Korea seems to have stabilized, and the number of newly diagnosed cases per day remains below $50 .{ }^{10}$ The Korean government is still warning about a possible second wave of new infections, emphasizing the importance of social distancing and personal hygiene.

During this COVID-19 pandemic, patients with acute stroke may be categorized into the following four groups: (1) Acute stroke patients with a laboratory-confirmed COVID-19; (2) Acute stroke patients not yet diagnosed with COVID-19, but in quarantine because of an epidemiological suspicion of exposure to COVID-19-close contact with confirmed cases or a recent trip, within the last 2 weeks, to COVID-19 affected regions or abroad; (3) Acute stroke patients not yet diagnosed with COVID-19, but are febrile or have respiratory symptoms; (4) Acute stroke patients not diagnosed with COVID-19 and who neither are febrile nor have respiratory symptoms.

If hospitals and emergency rooms establish pre-arrival screening measures for COVID-19, including assessment of travel history and respiratory symptoms, it would save time for acute stroke care. Otherwise, screening for COVID-19 should be performed for every patient before the protected code stroke is activated. ${ }^{8}$

Additional protective measures to mitigate the spread of SARS-CoV-2 transmission should be implemented in the following cases: (1) Acute stroke patients with a laboratory-confirmed COVID-19; (2) Acute stroke patients not yet diagnosed with COVID-19 but in quarantine because of an epidemiological suspicion of exposure to COVID-19.

\section{Measures to contain SARS-CoV-2 transmission during acute stroke care in the emergency room in case of out- of-hospital occurrence or at the place of onset in case of in-hospital stroke}

(1) All medical staff should use personal protective equipment
(PPE), including full-sleeved gown, N95 respirator, eye protection (goggles or face shields), and gloves.

(2) All non-intubated patients should wear a surgical mask.

(3) Minimize close contact with patients-a brief neurological examination suffices to assess the National Institute of Health Stroke Scale score.

(4) Limit neuroimaging studies to those that can detect large vessel occlusions and proceed to decide recanalization treatment; avoid advanced neuroimaging until COVID-19 is excluded.

(5) Secure a negatively pressurized or properly isolated room to monitor the stroke patient after intravenous thrombolysis or endovascular treatment.

(6) Minimize in-hospital patient transportation-use an isolation stretcher or wheelchair with negative pressure and clear out the hallway during in-hospital patient transportation.

\section{Measures to contain SARS-CoV-2 transmission during endovascular treatment in an angiography suite}

(1) Use a negatively pressurized angiography suite, if available. Otherwise, designate an angiography suite for treating a stroke patient with COVID-19 and prepare isolation measures beforehand. After treatment, complete disinfection and decontamination must be performed.

(2) Designate interventionists, technicians, and nurses for treating possible COVID-19 cases and make sure they are accustomed to proper donning and doffing of PPE.

(3) Turn off automatic doors to the suite. Shut down doors and restrict access to the suite during any procedure.

(4) Minimize the number of medical staff in the angiography suite during the procedure. One medical doctor may assume the role of crisis resource management. ${ }^{8}$

(5) The patient should wear a surgical mask during the procedure unless an oxygen mask or intubation is needed.

(6) Properly discard disposable items according to the institutional or national/regional guidelines.

(7) After the procedure, the patient should be admitted to a negatively pressurized or properly isolated intensive care unit or stroke unit.

The COVID-19 outbreak is ongoing, and the current situation is highly volatile. The statement and guidelines in this paper are based on scientific evidence and expert opinion available as of April 2020. It is recommended that each stroke center develops and updates an institutional protocol for providing safe and efficient stroke care amid the COVID-19 pandemic, based on its medical resources, local epidemics, and emerging 
prevention and treatment options against COVID-19.

The management of a patient with acute stroke who is neither diagnosed as COVID-19 nor in quarantine but has a fever or respiratory symptoms may depend on the local epidemiologic status of COVID-19. In an area with suspicion of widespread community transmission, applying the protected code stroke protocol to such a patient may be justified. It has been reported that asymptomatic COVID-19 patients may be contagious." Patients with acute stroke often require endotracheal suction or intubation, both of which can produce a large amount of virus-rich aerosols. In the long run, it should be discussed when and how to implement PPE and other containment measures against potentially contagious sources during acute stroke care in the emergency room.

Establishing regional or national stroke care networks is warranted. Shortage of medical resources can occur when hospitals are designated as COVID-19 dedicated centers or when hospitals shut down because of an in-hospital outbreak. These shortages may derange pre-existing regional stroke care systems. Therefore, centralized triage systems, including flexible rerouting and sharing of resource information, maybe the best option in these cases. Conventional stroke pre-notification by emergent medical services should include information on the diagnosis of COVID-19, exposure to COVID-19, fever, and respiratory symptoms.

The COVID-19 pandemic is rapidly spreading, and containing the virus and mitigating disease burden is currently the most important goal. However, physicians should endeavor to provide the best care to stroke patients even in these trying times.

The Korean version of this statement is provided as a Supplementary material.

\section{Supplementary materials}

Supplementary materials related to this article can be found online at https://doi.org/10.5853/jos.2020.01291.

\section{Disclosure}

The authors have no financial conflicts of interest.

\section{References}

1. Zhao J, Rudd A, Liu R. Challenges and potential solutions of stroke care during the coronavirus disease 2019 (covid-19) outbreak. Stroke 2020;51:1356-1357.
2. Infection prevention and control during health care when covid-19 is suspected. World Health Organization. https:// apps.who.int/iris/handle/10665/331495. 2020. Accessed April 27, 2020.

3. Lechien JR, Chiesa-Estomba CM, De Siati DR, Horoi M, Le Bon SD, Rodriguez A, et al. Olfactory and gustatory dysfunctions as a clinical presentation of mild-to-moderate forms of the coronavirus disease (COVID-19): a multicenter European study. Eur Arch Otorhinolaryngol 2020 Apr 6 [Epub]. https:// doi.org/10.1007/s00405-020-05965-1.

4. Kim ES, Chin BS, Kang CK, Kim NJ, Kang YM, Choi JP, et al. Clinical course and outcomes of patients with severe acute respiratory syndrome coronavirus 2 infection: a preliminary report of the first 28 patients from the Korean cohort study on COVID-19. J Korean Med Sci 2020;35:e142.

5. Li Y, Wang M, Zhou Y, Chang J, Xian Y, Mao L, et al. Acute cerebrovascular disease following covid-19: a single center, retrospective, observational study. SSRN. https://doi. org/10.2139/ssrn.3550025. 2020. Accessed April 27, 2020.

6. Mao L, Wang M, Chen S, He O, Chang J, Hong C, et al. Neurological manifestations of hospitalized patients with covid-19 in Wuhan, China: a retrospective case series study. medRxiv. https://doi.org/10.1101/2020.02.22.20026500. 2020. Accessed April 27, 2020.

7. Temporary emergency guidance to US stroke centers during the COVID-19 pandemic. Stroke 2020 Apr 1 [Epub]. https:// doi.org/10.1161/STROKEAHA.120.030023.

8. Khosravani H, Rajendram P, Notario L, Chapman MG, Menon BK. Protected code stroke: hyperacute stroke management during the coronavirus disease 2019 (COVID-19) pandemic. Stroke 2020 Apr 1 [Epub]. https://doi.org/10.1161/ STROKEAHA.120.029838.

9. Jin $H$, Hong $C$, Chen $S$, Zhou $Y$, Wang $Y$, Mao L, et al. Consensus for prevention and management of coronavirus disease 2019 (covid-19) for neurologists. Stroke Vasc Neurol 2020 Apr 1 [Epub]. http://dx.doi.org/10.1136/svn-2020-000382.

10. Updates on Covid-19 in Republic of Korea: 13 April 2020. Korea Centers for Disease Control \& Prevention. https://www. cdc.go.kr/board/board.es?mid=a30402000000\&bid=0030. 2020. Accessed April 27, 2020.

11. Rothe C, Schunk M, Sothmann P, Bretzel G, Froeschl G, Wallrauch C, et al. Transmission of 2019-nCoV infection from an asymptomatic contact in Germany. N Engl J Med 2020;382:970971. 


\title{
Supplementary material
}

\section{COVID-19 유행 시기의 병원 내 및 지역 사회 급성 뇌졸중 환자 대응 및 진료에 관한 의학적 권고}

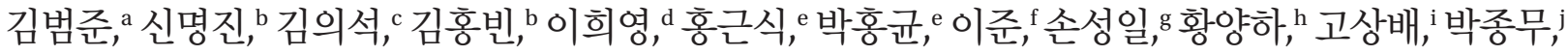
나정호, ${ }^{\mathrm{k}}$ 권순억, ${ }^{,}$김종성, ${ }^{1}$ 허지회, ${ }^{\mathrm{m}}$ 이병철, ${ }^{\mathrm{n}}$ 윤병우, ${ }^{\mathrm{i}}$ 배희준 ${ }^{\mathrm{a}}$

\author{
a분당서울대학교병원 신경과 및 경기권역심뇌혈관질환센터 \\ 분당서울대학교병원 감염관리실 \\ c분당서울대학교병원 내과 및 분당서울대병원 감염관리실 \\ d분당서울대학교병원 공공의료사업단 및 경기도 감염관리본부 \\ e인제대학교일산백병원 신경과 \\ f영남대학교병원 신경과 \\ 9 계명대학교 동산병원 신경과 \\ $\mathrm{h}$ 경북대학교병원 신경과 \\ '서울대학교병원 신경과 \\ j을지대학교 을지병원 신경과 \\ k인하대학교병원 신경과 \\ '서울아산병원 신경과 \\ ${ }^{m}$ 세브란스병원 신경과 \\ n한림대학교 성심병원 신경과
}

급성 뇌졸중 환자의 예후 향상을 위해서는 즉각적인 환자 이송과 진료 그리고 뇌졸중 집중 치료실을 포함한 입원 치료가 필수적이다. 최근 사 스 코로나바이러스-2 (severe acute respiratory syndrome coronavirus 2 [SARS-CoV-2]) 코로나감염증-19 (coronavirus disease 2019 [COVID-19]) 가 전 세계적으로 확산되면서 필수 의료 인력과 자원이 부족해져 기존 의료 체계에 상당한 혼란과 피로를 유발하고 있고, 의료 현장에서 급성 뇌졸중 환자들이 적절한 뇌졸중 진단 및 치료를 받지 못할 가능성에 대 한 우려가 증가하고 있다. ${ }^{1}$ 또한 뇌졸중 환자의 응급 진료 및 급성기 치 료 과정에서 뇌졸중센터 내의 의료진을 SARS-CoV-2 감염으로부터 보 호할 수 있는 조치를 강구할 필요가 있다. 아직 COVID-19의 역학, 치료, 감염관리 등에 대해 충분히 알려져 있지 않지만, 뇌졸중 환자와 의료 진을 위하여 현재까지 알려진 근거에 기반하여 잠정적인 뇌졸중센터 운영 권고안을 제시하고자 한다. 본 권고안은 2020년 4월 중순 시점의 COVID-19 유행 역학 및 발표된 자료에 근거하였다. 각 뇌졸중센터는 각 병원의 상황, 지역의 역학적 특성 및 COVID-19 유행 역학의 변화 등 을 고려하여 개별적인 지침을 운용할 필요가 있다.

COVID-19는 기침, 재채기, 혹은 대화 중에 비산하는 비말(droplet)을 통하여 바이러스(SARS-CoV-2)가 우리 몸의 호흡기계 점막으로 침투하 면서 전염되는 것으로 알려져 있다. 그리고 COVID-19 감염자는 발열, 인두통, 기침, 흉통, 호흡 곤란, 두통, 근육통 등 호흡기 감염 증상을 비교 적 흔히 보이나 구토 및 설사 등의 위장관계 증상을 보이기도 한다. 초 기 증상은 가벼운 편이나 발병 5-7일째 폐렴이 진행할 수 있고 초기부 터 상기도에서 많은 양의 바이러스를 배출한다고 알려져 있다..$^{2,3}$ 일부 환자에서 초기 미각 및 후각 기능 소실이 있을 수 있다는 보고도 있다. ${ }^{4}$
COVID-19 환자 중 약 36\%가 신경학적 증상을 호소한다고 알려져 있으나, 그 대부분은 어지럼증(17\%), 두통(13\%) 등 전신 감염에 동반 한 비특이적 증상이다. COVID-19 감염자 중 6\%에서 뇌졸중이 발생했 다는 보고가 있는데, 발생 시점은 COVID-19 증상 발생 후 중앙값 10일 째였다. ${ }^{5,6}$ 뇌경색의 주된 발병 기전은 위중한 전신 상태로 인한 혈액 응고 항진(hypercoagulability) 및 바이러스에 의한 심근염 등 심장 기능 부전에 의한 심장탓 색전증(cardioembolism)이었다.

현재 미국뇌졸중학회에서 몇 개의 뇌졸중 관련 권고안이 사전 출 판되어 학계의 검증을 받는 중이며, ${ }^{1,7,8}$ 최근 논설은 COVID-19로 인하 여 통상적인 진료 활동이 제한되는 상황을 대비하여 다음과 같은 준 비를 할 것을 촉구하고 있다. 첫째, 뇌졸중 치료시스템을 집중화하여 충분한 의료 자원을 확보해야 하고 둘째, 뇌졸중 환자 발생 시 공공환 자이송체계를 통하여 급성기 뇌졸중 치료가 가능한 뇌졸중센터로 환 자들이 직접 내원할 수 있도록 홍보가 필요하며 셋째, 개별 뇌졸중센 터에서는 발열 및 호흡기계 증상이 동반된 환자에게 "protected code stroke" 이라는 추가적인 COVID-19 확산 방지 조치를 한 원내 뇌졸중 치료체계를 가동해야 한다.

COVID-19가 심각한 지역 사회 감염으로 확산된 북부 이탈리아에 서는, 이로 인하여 거의 모든 통상적 심혈관 질환 환자 치료가 중단된 상황이라 하며, 이에 롬바르디 지방정부는 심혈관 시술 가능 병원 55 개 중 13 개를 허브로 지정하여 응급 심혈관 시술만 시행하도록 강제 하였다. ${ }^{9}$

미국뇌졸중학회에서는 미국 내의 급격한 COVID-19 확산에 대응 하여 임시 응급 지침(temporary emergency guidance)이란 이름으로 
개인 보호 장비(personal protective equipment), 진료 현장에 즉각 투 입될 수 있는 의료진, 충분한 병상, COVID-19 시대에 부합되는 응급환 자 이송 체계를 시급히 확보할 것을 촉구하고 있다.

중국에서 발표된 문헌은, COVID-19 고위험 지역의 뇌졸중 환자에 게 뇌 컴퓨터단층촬영술(computed tomography [CT])을 시행할 때 흉 부 CT를 함께 촬영할 것을 권고하고 있다. ${ }^{10}$

2020년 4월 초 현재 한국에서의 코로나 감염은 비교적 안정적으로 관리되고 있는 것으로 보이나, 코로나바이러스감염증-19 중앙재난안 전대책본부는 장기적인 관점에서 COVID-19 관리를 위한 사회적 거리 두기 및 의료기관 내 감염 예방 활동이 필요함을 홍보하고 있다."

COVID-19와 관련하여 급성 뇌졸중 환자를 다음 네 가지 범주로 나누어 볼 수 있을 것이다.

(1) COVID-19가 이미 확진된 환자

(2) COVID-19 확진은 받지 않았으나, 2주 이내의 확진자 밀접 접 촉, COVID-19 지역 유행이 있는 국가 방문 및 국내 집단 발병 지역 방문 등의 역학적 연관성이 있어 자가 격리 상태인 환자

(3) COVID-19 확진을 받지 않았으며 역학적 연관성이 없어 자가 격리 중이지 않으나, 내원 시점에 발열 혹은 호흡기계 증상이 있는 환자

(4) 무증상 뇌졸중 환자

현재 모든 대한민국의 의료 기관은 COVID-19 환자와 관련한 선별 진료 체계를 가동하고 있다. 따라서 개별 뇌졸중센터에서 뇌졸중 환 자를 위한 별도의 COVID-19 의심 환자 진단 및 분류 체계를 가동하 기보다, 각 병원의 선별진료소, 응급실, 질병관리본부, 소방본부 등 에서 운영 중인 체계를 통하여, 뇌졸중 의심 환자의 COVID-19의 감 염 상태를 파악하는 것이 현실적이다.

상기 네 가지 분류 중에서 (1) COVID-19 확진 환자이거나 (2) COVID-19 확진은 받지 않았으나 자가 격리 상태인 환자 중 임상 증 상 및 영상검사 등으로 COVID-19 감염증의 배제가 어려운 경우에 해 당하는 경우, 각 병원은 code stroke 등의 원내 뇌졸중 치료 체계를 활성화하면서 아래와 같은 COVID-19에 대한 확산 방지 조치를 가동 할 필요가 있다.

\section{COVID-19 감염 가능성이 있는 급성 뇌졸중 화자에 대한 원내 바이러스 확산 방지 조치(응급실 및 원내 발생인 경우 병실)}

적용 대상 환자: (1) COVID-19 확진 환자이거나 (2) COVID-19 확진은 받지 않았으나 자가 격리 상태인 환자 중 임상 증상 및 영상검사 등 으로 COVID-19 감염증의 배제가 어려운 경우

(1) 의료진의 개인 보호 장비 착용: 뇌졸중센터 의료진은 전신을 가릴 수 있는 일회용 가운 또는 전신 보호복, N95 마스크, 보안 경(고글 혹은 안면 보호구), 일회용 장갑을 착용한다.

(2) 환자의 마스크 착용: 환자에게 외과용 마스크(surgical mask)를 착용 시켜 비말 확산을 방지한다.

(3) 신경학적 검진 및 NIHSS (National Institutes of Health Stroke Scale) 평가를 위한 밀접 접촉은 최소한으로 한다.

(4) 뇌영상검사는 COVID-19 감염 검사가 음성으로 통보될 때까지,
정맥 내 및 동맥 경유 혈관 재개통 치료 필요 여부를 결정하기 위한 검사까지만 시행할 것을 권고한다.

(5) 정맥 내 혈전 용해제 투여 후 환자의 신경학적 상태, 혈압 등을 관찰할 수 있는 음압 병상 혹은 격리 시설을 확보할 것을 권고 한다. 각 뇌졸중센터의 물리적 상황을 고려하여 개별 센터의 지침을 개발할 필요가 있다.

(6) 환자의 이동을 최소한으로 한다. 영상검사를 위한 이동 시 타 인과의 접촉을 최소한으로 제한할 수 있도록, 전용 통로를 확 보할 것을 권고한다. 환자 이동 시 음압 카트 및 음압 휠체어를 보유한 경우 사용을 권고하며, 음압 카트 사용이 어려운 경우 환자에게 개인 보호 장비를 착용시킨다.

COVID-19 감염 가능성이 있는 급성 뇌졸중 환자의 혈관 재개통 시술과 관련된 추가적 확산 방지 조치(혈관 조영실)

적용 대상 환자: (1) COVID-19 확진 환자이거나 (2) COVID-19 확진은 받지 않았으나 자가 격리 상태인 환자 중 임상 증상 및 영상검사 등 으로 COVID-19 감염증의 배제가 어려운 경우

(1) 음압 시설이 설치된 혈관 조영실에서 시술할 것을 권고한다. 음압 시설이 없는 경우, 본 조치의 적용 대상 환자의 치료를 위 한 혈관 조영실을 사전에 지정하고 기존 일반 환자와 분리해서 시행할 수 있는 방안을 고려한다. 시술 후 지침에 따른 방역 및 소독 조치를 시행한다.

(2) 본 조치의 적용 대상 환자에게 혈관 재개통 시술을 할 인력을 사전에 지정하고, 이들에게 보호 장비 착용 및 행동 지침에 대 한 교육을 실시한다.

(3) 환자 입실 후 자동문을 수동 상태로 전환하여 닫아 두며, 입구 에 COVID-19 의심 환자 시술 중임을 표기하여 의료진의 접근 을 제한한다.

(4) 혈관 재개통 시술 시 혈관 조영실 내부는 필요한 최소한의 인 원만 상주하도록 하며, 조영실 밖에 의료진이 상주하여 필요한 의학적 조치, 물품 준비 및 전달, 전반적인 안전 조치 관리 등을 담당한다.

(5) 혈관 재개통 시술 중 환자는 외과용 마스크를 착용한다.

(6) 시술 후 조영실 내에서 의료진 및 환자에게 사용된 모든 일회 용 물품은 격리의료폐기물로 분류하여 폐기하며, 재처리가 필 요한 경우 의료기관에서 권고하는 지침에 따른다.

(7) 동맥 내 혈관 재개통 시술을 받은 환자는 시술 후 활력 징후 및 신경학적 악화 관찰을 위해 음압 격리된 중환자실 혹은 집중치 료실로의 입원을 권장한다. COVID-19 확진을 받은 뇌졸중 환 자는 되도록 음압 격리 시설로 입원하는 것을 권고하나, 이는 각 병원의 병상 현황을 고려하여 개별적으로 결정한다.

COVID-19의 확산은 현재 진행 중이며, COVID-19 감염증 역시 역동 적으로 변화하고 있다. 따라서 본 과학적 성명은 2020년 4월의 현황과 이용 가능한 과학적 근거 그리고 현시점에서의 전문가 판단에 근거하 고 있다. 따라서, 각 의료 기관에서 이용 가능한 자원, 지역 사회 유행 상황, 치료제 혹은 백신 개발 등을 고려하여, 개별 뇌졸중센터의 프로 
토콜을 개발하고 이를 계속 개정하는 것이 필요하다.

COVID-19 확진을 받지 않았으며 역학적 연관성이 없어 자가 격리 중 이지 않으나 발열 혹은 호흡기계 증상이 있는 환자에 대해서, 2020년 4월 2일 발간된 국내 대응 지침에는 별도의 방역 조치를 언급하지 않고 있다. ${ }^{12}$ 다만, COVID-19 바이러스가 이미 지역 사회 유행 단계로 확산된 지역에서는, 무증상 감염자로부터 의료진이 전염될 가능성이 있다. ${ }^{13}$ 또 한 뇌졸중 환자는 비인두 흡인, 기관내 삽관 등 에어로졸 발생 가능성이 높은 시술을 받게 되는 경우가 흔하다.

본 과학적 성명에서는 COVID-19 확진을 받지는 않았으나 호흡기계 증상이 있는 환자에 대해서 명백한 권고 사항을 제시하지 않으며, 개 별 뇌졸중센터의 대응 지침 개발을 권고한다. 이에 대해서는 장기적으 로 COVID-19 유행 종식 이후의 통상적인 원내 감염 방지 조치의 일환 으로 계속 논의하고 연구할 필요가 있다.

COVID-19의 강한 전염력으로 인하여, 병원 내 감염이 발생하고 이 후 해당 의료기관이 폐쇄되는 사건이 종종 발생하고 있다. 지역 사회 에서 급성기 뇌졸중 진단 및 치료를 담당하던 병원이 폐쇄되면서, 지 역 사회의 뇌졸중 환자들이 원거리에 있는 병원으로 이동하거나, 근거 리에 있으나 적절한 뇌졸중 진료가 어려운 병원으로 이송되는 경우가 발생할 수 있다. 이로 인해 뇌졸중 치료 가능 시기를 넘겨 필요한 혈관 재개통 치료를 받지 못하게 될 가능성이 있다.

따라서 주요 의료 기관이 COVID-19 원내 감염 등으로 폐쇄되는 경 우, 소방청 및 지역 119 안전신고센터 등과 협의하여 지역 사회 뇌졸중 이송 및 치료 체계를 재정립하는 것이 필요하다. 통상적인 뇌졸중 의 심 환자 사전 통보 시 COVID-19 감염 여부, 격리 여부 및 발열 혹은 호 흡기계 증상 동반 여부를 포함할 수 있을 것이다. 또한, 혈관 재개통 치 료 혹은 뇌 수술이 필요한 환자는 응급 진료가 가능한 뇌졸중센터로 이송하고, 뇌졸중의 가능성이 낮거나 치료 가능 시간(time window)을 초과한 환자는 지역 응급 센터로 이송하는 등의 조치가 있어야 할 것 이다. 이를 위하여 각 지역의 소방청, 지역 및 권역의 주요 뇌졸중센터 등의 적극적인 협력이 요청된다.

\section{Supplementary references}

1. Zhao J, Rudd A, Liu R. Challenges and potential solutions of stroke care during the coronavirus disease 2019 (covid-19) outbreak. Stroke 2020;51:1356-1357.

2. Infection prevention and control during health care when covid-19 is suspected. World Health Organization. https:// apps.who.int/iris/handle/10665/331495. 2020. Accessed April 27, 2020.

3. Kim ES, Chin BS, Kang CK, Kim NJ, Kang YM, Choi JP, et al. Clinical course and outcomes of patients with severe acute respiratory syndrome coronavirus 2 infection: a preliminary report of the first 28 patients from the Korean cohort study on COVID-19. J Korean Med Sci 2020;35:e142.
4. Lechien JR, Chiesa-Estomba CM, De Siati DR, Horoi M, Le Bon SD, Rodriguez A, et al. Olfactory and gustatory dysfunctions as a clinical presentation of mild-to-moderate forms of the coronavirus disease (COVID-19): a multicenter European study. Eur Arch Otorhinolaryngol 2020 Apr 6 [Epub]. https:// doi.org/10.1007/s00405-020-05965-1.

5. Li Y, Wang M, Zhou Y, Chang J, Xian Y, Mao L, et al. Acute cerebrovascular disease following covid-19: a single center, retrospective, observational study. SSRN. https://doi. org/10.2139/ssrn.3550025. 2020. Accessed April 27, 2020.

6. Mao L, Wang M, Chen S, He Q, Chang J, Hong C, et al. Neurological manifestations of hospitalized patients with covid-19 in Wuhan, China: a retrospective case series study. medRxiv. https://doi.org/10.1101/2020.02.22.20026500. 2020. Accessed April 27, 2020.

7. Temporary emergency guidance to US stroke centers during the COVID-19 pandemic. Stroke 2020 Apr 1 [Epub]. https:// doi.org/10.1161/STROKEAHA.120.030023.

8. Khosravani H, Rajendram P, Notario L, Chapman MG, Menon BK. Protected code stroke: hyperacute stroke management during the coronavirus disease 2019 (COVID-19) pandemic. Stroke 2020 Apr 1 [Epub]. https://doi.org/10.1161/ STROKEAHA.120.029838.

9. Guo T, Fan Y, Chen M, Wu X, Zhang L, He T, et al. Cardiovascular implications of fatal outcomes of patients with coronavirus disease 2019 (COVID-19). JAMA Cardiol 2020 Mar 27 [Epub]. https://doi.org/10.1001/jamacardio.2020.1017.

10. Jin H, Hong C, Chen S, Zhou Y, Wang Y, Mao L, et al. Consensus for prevention and management of coronavirus disease 2019 (covid-19) for neurologists. Stroke Vasc Neurol 2020 Apr 1 [Epub]. http://dx.doi.org/10.1136/svn-2020-000382.

11. Central Disaster Management Headquaters of Coronavirus Disease 2019. 코로나바이러스감염증-19 중앙재난안전대책 본부 정례브리핑(4월 5일). Ministry of Health and Welfare. http://ncov.mohw.go.kr/tcmBoardView.do?brdld=\&brdGubun $=\&$ dataGubun=\&ncrContSeq=353931\&contSeq=353931\&b oard_id=\&gubun=ALL. 2020. Accessed April 27, 2020.

12. Central Disease Control Headquarters. 코로나바이러스감염 증-19 대응 지침 지자체용 (7-4판). Korea Center for Disease Control and Prevention. https://www.cdc.go.kr/board/board. es? $\mathrm{mid}=$ a 20507020000\&bid=001 $\&$ \&act $=$ view $\&$ list no $=366712 \&$ tag $=\& n$ Page $=1.2020$. Accessed April 27, 2020.

13. Rothe $C$, Schunk M, Sothmann P, Bretzel G, Froeschl G, Wallrauch $C_{1}$ et al. Transmission of 2019-nCoV infection from an asymptomatic contact in Germany. N Engl J Med 2020;382:970971. 